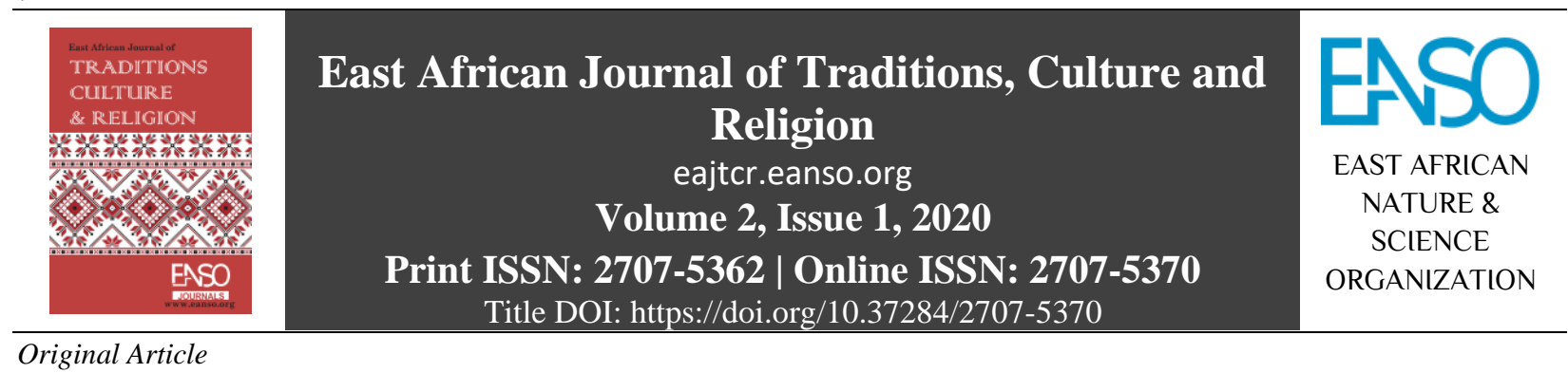

\title{
What Has Science to Do with Religion? A Looming Challenge of Traditional and Religious Practices on Curbing the Spread of COVID-19 Pandemic in Kenya
}

\author{
Bernard Alwala $^{1 *}$ \\ ${ }^{1}$ Department Economics and Humanities, School of Arts and Social Sciences, Rongo University, Main Campus, Kenya. \\ ${ }^{*}$ Correspondence Email: alwalaben@ rocketmail.com \\ ORCID: https://orcid.org/0000-0002-2978-7498
}

Article DOI: https://doi.org/10.37284/eajtcr.2.1.152

Date Published:

$\begin{aligned} & 22 \text { May } 2020 \text { ABSTRACT } \\ & \text { Keywords: } \begin{array}{l}\text { The association between religion and science is a theme of unceasing discussion } \\ \text { experienced in Kenya. To what degree are religion and science (e.g., medicine) }\end{array} \\ & \text { Science, } \text { well-matched? Are religious beliefs occasionally helpful to science, or do they } \\ & \text { Religion, } \text { inexorably pose hindrances to scientific inquiry? Are we able to manage } \\ & \text { Pandemic, } \text { COVID-19 through religion, or medicine, or both medicine and prayer? The } \\ & \text { COVID-19, } \text { interdisciplinary field of science and religion, also called theology and science } \\ & \text { aenya, } \text { aims at answering these among other questions. The field studies ancient and } \\ & \text { current relations among these fields and offers philosophical examinations of } \\ & \text { Coronavirus. } \\ & \text { how they correlate hence able to provide a holistic approach to combatting the } \\ & \text { corona-virus pandemic in Kenya. This paper provides an overview of the topic } \\ & \text { and discussions in science and religion, the role of spirituality/religion in health, } \\ & \text { and how traditional and religious practices may contribute to the spread of } \\ & \text { Corona-virus. Section 1, outlines the scope of both fields, and how they } \\ & \text { intersect; section } 2 \text {, focuses on health and spirituality and section } 3 \text { concludes } \\ & \text { by looking at the looming challenges that religion and culture may present to the } \\ & \text { scientific directives on the spread of COVID-19 and ends by proposing } \\ & \text { strategies on community-directed programs by the Ministry of Health. }\end{aligned}$

\section{APA CITATION}

Alwal, B. (2020). What Has Science to Do with Religion? A Looming Challenge of Traditional and Religious Practices on Curbing the Spread of COVID-19 Pandemic in Kenya. East African Journal of Traditions, Culture and Religion, 2(1), 23-33. https://doi.org/10.37284/eajtcr.2.1.152

\section{CHICAGO CITATION}


Alwala, Bernard. 2020. "What Has Science to Do with Religion? A Looming Challenge of Traditional and Religious Practices on Curbing the Spread of COVID-19 Pandemic in Kenya”. East African Journal of Traditions, Culture and Religion 2 (1), 2333. https://doi.org/10.37284/eajtcr.2.1.152.

\section{HARVARD CITATION}

Alwala, B. (2020) "What Has Science to Do with Religion? A Looming Challenge of Traditional and Religious Practices on Curbing the Spread of COVID-19 Pandemic in Kenya”, East African Journal of Traditions, Culture and Religion, 2(1), pp. 2333. doi: 10.37284/eajtcr.2.1.152.

\section{IEEE CITATION}

B. Alwala, "What Has Science to Do with Religion? A Looming Challenge of Traditional and Religious Practices on Curbing the Spread of COVID-19 Pandemic in Kenya”, EAJTCR, vol. 2, no. 1, pp. 23-33 May. 2020.

\section{MLA CITATION}

Alwala, Bernard. "The Fate of Prosperity Gospel in Kenya." East African Journal of Traditions, Culture and Religion, Vol. 2, no. 1, May. 2020, pp. 23-33, doi:10.37284/eajtcr.2.1.152.

\section{INTRODUCTION}

The objective of this paper is to assess the connection between science (medicine and healthcare) and religion in order to suggest how the Ministry of Health in Kenya (physicians and other health care workers) can holistically respond when managing a COVID-19 patient in Kenya.

Before the entry of the COVID-19 pandemic in Kenya, religion was believed to provide an essential service to humanity. Religion was fundamental because it infused each aspect of Kenyans life. It was closely tied with the commercial, communal, political, and domestic life of Kenyan acting as one big, closely-knit kinship group of the family, clan, and tribe. Recently, this idea was changed in Kenya by the governmental closure of public and social spaces that do not provide essential services to humanity. Places of worship inclusive of churches, shrines, and mosques suffered the same fate. Some religious traditions, especially Christianity, which has most believers reject the idea as succumbing to the works of demons. Christians continued to state that the pandemic is a punishment from God; the only way out of this was through repentance to be done in the places of worship. On the other hand, others support this with Biblical references.

The key question worth investigating is whether Coronavirus needs a religious response, scientific response, or both religion and science. The role of religion in the fight against the Coronavirus pandemic was also criticized by some during the call of national prayer day by the Head of State os Kenya; it was argued that it should be left to scientists. Here we get a conflicting association between religion and science hence leads us to discuss whether science and religion can mutually interact.

\section{INTERACTIONS BETWEEN RELIGION AND SCIENCE}

The connection between science and religion is the subject of contentious discussion in philosophy, religion, and theodicy. The following questions are commonly asked. What degree are religion and science integrable? Are religious beliefs occasionally favorable to science, or do they unavoidably pose complications to scientific investigation? The methodical study of the relationship between science and religion started in the 1960 s by scholars such as Ian Barbour (1966) and Thomas F. Torrance (1969) who defied the predominant opinion that science and religion were either in conflict or unresponsive to each other. Barbour, for example, was of four views on the association between religion and science, that is, conflict, independence, dialogue, and integration, while Stephen Gould coined the NOMA principle ("non-overlapping Magisteria"). This paper supports one of Barbour's views on the association between religion and science. In this case, we use dialogue to holistically fight the COVID-19 pandemic not only in Kenya but the whole world. There are many areas in which religion and science are similar in their investigations. Rayn Kleipe (2011) isolated six of the most significant ones:

To begin, both science and religion are grounded upon endless pursuit for superior information, understanding, and wisdom of the cosmos. Major 
world religions emphasize that philosophers and researchers must acquire self-information, the cosmos of wisdom, and knowledge within the cosmos. Major beliefs strongly underline the impression that those who search for knowledge must obtain wisdom, understanding, and self-knowledge to become familiar with consciousness and the Supreme Being. This is done using Holy texts like the Bible and Quran, traditions, and reflections on the cosmos. Similarly, science underlines the idea that scientists and intellectuals must recognize all forms of knowledge in the cosmos to become nearer to reality. This is done using workbooks, allegory, theories, and philosophies. With all of this in mind, science and religion seem to function as two autonomous schools of thought with a shared platform.

Secondly, both are on ideology based on faith. Religion is grounded on the trust in a Supreme Being or God as in Christianity or Allah as in Islam. His decree and the authority over the universe and all that exist in it. While science is based on reliance on the decrees of nature and power over all that exists. The association between science and religion can be well-defined by John F. Haught, who specified that, the impartial yearning for knowledge out of which science cultivates and flourishes, finds its genuine authorization in a religious knowledge of the cosmos (Haught, 1995).

Religion's prerogative that nature is a limited, intelligible, and rational, offers an overall idea of experiential that reliably fosters the scientific pursuit for information and releases science from association with curtailing ideas. Science to get ground must root itself on priori belief that the cosmos is a realistically well-organized sum of realities (Haught, 1995). Religion becomes the source of previously-formulated thought pattern that is used in science.

Thirdly, is the presence of both science and religion in the ancient civilization. Historically, the connection between religion and science was existing in the olden civilization of, Egypt, Maya, and Aztec. In the above, they composed a religiongovernmental system of ruling with the sovereign caste above was being helped by selected priests who oversee the temple. The most motivating point in this system was that priests were selected based on their noble blood displaying solid technical knowledge in scientific disciplines. Upon taking office, these priests would work together with the scribe caste to throng the knowledge. The above clearly indicates the fact that science and religion mutually benefit.

Fourth, though some people like Bryan Appleyard, rejects the mutual connection between religion and science. He positions that science and religion are entirely dissimilar ways of knowledge (Kleipe, 2011). The majority essentially view the two areas of attention as reciprocally exclusive. However, Rayn Kleipe in his paper rejects the above as somewhat dismissive over-generalization. He enlightens that neither religion deals solely with the unseen while science with the material world, or else it will oppose two features of science, i.e., hypothesis and theory. Carl Hempel supports the above statement when he argued about the presence of hypothetical entities (objects that display strong symbols of existing but have never been experienced in reality). In a summarized way, he said that if science was to study only the empirical, scientists would only have a restricted degree of knowledge and a narrow presentation of causality within the cosmos (Hempel, 1966). Science must use theoretical entities to gain a more complete and precise interpretation of things in the cosmos. In this manner, science needs religion to gain much more on their area of research hence presents more convincing truth that presents a solution to the world. Historically, science is shaped by theories that were later proved by the use of physical means. For example, Pasteur's invisible pathogens, Newton's unseen gravitational force, Einstein's imperceptible protons among others. It is a fact that science thrives on ideas and possibilities, some scientific ideas are fashioned just for approval or rejection of the practicability of a concept.

Fifth, some practices within world religions contribute to science and have been proved to be scientifically valid. For many years now, Judaism, African Traditional Religion, Christianity, Islam, Hinduism, and many other beliefs have practiced firm nutritional regulations. Some drain blood from slaughtered animals, remove fat in meat, not taking pork. Science confirms these regulations to be a sound and healthier way of living. For example, Judaism, rejects pork and shellfish, meat and milk 
may not be combined and meat must be ritualistically slaughtered and salted (KashrutJewish dietary laws). Islam nutritional constraint rejects meat from animals that die on their own, blood, the meat of pig (Quran 2:173). Some other religious practices are the disposal of human waste, the isolation of persons with infectious diseases, the immediate internment of the deceased. These customs have scientifically verified themselves as operative procedures for reducing the spread of ailments in communities where they are practiced. Some of the above ways like isolation of the sick, proper disposal of human waste, and proper diet have been suggested currently by the Centre of Disease Control concerning the COVID-19 pandemic.

Lastly, in additional resemblance amid religion and science, whereby all of them claim to hold the "actual" reality. Several perfectionists and scholars sight science and religion as equally exclusive hence do not have any point of contact. Philosophical empiricism, for example, is grounded on the impression that what is real must be experienced. According to Crick, there is no necessity for any additional kind of clarification than that sourced from pure science, subsequently no kind of authenticity than the purely corporeal (Kleipe, 2011). Many religions also teach similar dogma, many denominations in the world teach that the Bible teaches the truth, science should be rejected if it contradicts the scripture. This means that for a universally accepted reality or knowledge, science and religion should blend.

There are numerous equivalents between science and religion, and minute purpose to place them entirely at likelihoods. Some historical indication even designates that science and religion may have probably started from one single foundation but later branched off but still leads to similar direction while interlacing and crisscrossing at several points in human experience. Observing the schools of thought as conflicting is to commit a logical fallacy of the false paradigm. Those who "choose" to capitalize on either side and the expense of the other acquire limited knowledge considering the fact that, the universe is enormous. For this reason, to control the COVID -19 pandemic is a matter of symbiotic action from both science and religion.

\section{HOW SPIRITUALITY/RELIGION IMPACTS ON SCIENCE (E.G. MEDICINE)}

\section{Spirituality}

Spirituality is commonly given a descriptive definition. The term has its root in Latin spirare, meaning, to inhale or breathe. In contemporary use, the term embraces an extensive variety of anthropological experiences. For example, old religions, new age dogma, individual spiritual experiences, and the search for sense in life expectancy (Miller \& Thorensen, 2003).

Simpson and Weiner, in the Oxford English Dictionary, offers two correlated themes. First, the term signifies life expectancy's greatest dynamic matters and apprehensions. Second, it is understood as idiosyncratic structures of life including the human senses, such as vision and hearing (Weiner, et al., 1991). The Association of American Medical Colleges gives the term a broad descriptive definition: Spirituality is known as an aspect that backs to well-being in most people (D'Souza, 2007). In this paper, we define spirituality as a sense of connection to something bigger than ourselves in search of meaning in life. The various spiritual strategies that may contribute to health include, meditation, prayer, spiritual reading, and yoga.

\section{Religion}

Compared to spirituality, religion is defined as piety incarnated at the community and cultural level. Religion may even transform culture. Religion is derived from the Latin word religio, meaning "to bind back or to tie." Like "spirituality," "religion" suffers from a variety of descriptive definitions. The term is progressively being used by researchers in the limited view as doctrines, rites, and traditions founded by a specific institution (Testerman, 1997). For this paper, our operative definition of as the service and worship of God or the supernatural.

Spiritual or religious activities have a great impact on the health of the whole person. This is because, patients are not to be seen only in terms of a disease, but the whole person should be attended to; that is spiritual, physical, and psychological. This is also in support of the World Health Organization (WHO), which categorizes, health in four 
categories; physical, social, mental, and spiritual health. Several empirical studies have shown a great connection of spirituality or religious activities on good health, coping with illness, recoveries, and even low mortality rates.

There is a sign that several extremely ill patients exercise pious beliefs to manage through ailment (Koenig et al., 1992). Religious/spiritual participation is a common practice that foresees fruitful management with bodily illness (Koenig et al., 2001). Studies by Koenig et al in another research, indicate that, high inherent spirituality expects an additional speedy reduction in depression, particularly in patients whose bodily purpose is not showing signs of improvement (Koenig et al., 1998). In a meta-analysis of more than 850 studies probing the connection between spiritual participation and several facets of psychological health, a majority of studies displayed that persons experience better mental health and acclimatize better to trauma if they are spiritual (Koenig et al., 2001). Another scrutiny of 350 people, an investigation showed that people who are notoriously religious are physically healthy, lead healthier lifestyle nutrition, and need fewer healthy medical management (Hummer et al., 1999).

According to Ellison \& Levin (1998), other research designates that piety seems to unquestionably associate with bodily well-being. For example, fatalities are lesser among spiritual individuals who regularly join spiritual exercises and contemplatives of spirituality (Shahabi et al., 2002). Seybold and Hill (2001), corroborate the above studies when he positions that, nearly all investigations involving the consequence of spirituality on people's well-being have demonstrated a constructive ascription to their existence on human health.

There are four protuberant paths in which spirituality can impact well-being according to Oman and Thorensen: health actions (through recommending required diet); social support (people can share experiences with chaplains of hospitals and relatives; psychological states (where the mind is at peace with humanity and nature) and 'psi' influences (supernatural laws and principles).
These pathways act indirectly to the well-being of an individual (Oman \& Thorensen, 2002).

The prominent pathways should be included in the management of COVID-19 patients. This is to initiate full recovery. The diet recommendation to boost the immunity, social support to avoid stigmatization of the recovered patients, and involvement of chaplains and clergies to attend to those in isolation centers.

On the importance of spirituality in medicine, Russel D's ouza (2007), isolated three of the most significant ones: First, $\mathrm{He}$ states that there is a connection of science and humanism for the patient's well-being. Though science and medicine usually oppose each other, both science and medicine can be blended under medical humanisma shared method that rests on an understanding of anthropological strength and well-being by use of numerous methods i.e. biomedical, spiritual, philosophical, and sociological. This assist clinicians to enhance their way to remedy, discharge, and comfort those who are ill. The integration of these approaches aims at the holistic treatment of those who are ill.

Secondly, doctors as healers through the caring relationship with the patient require calling of an individual's inner strength which includes spiritual resources among others. Respecting the patients' religious beliefs and practices is an important system that is necessary for their integral wellbeing and recovery. Lastly, consideration of religiosity and spirituality of the parent. It is all Patients desire to be understood and given medical services as a complete being. This whole-person involves bodily, emotional, societal, and spiritual dimensions. Ignoring any of the above makes patients feel incompletely attended to and may interfere with recovery.

Religion continues to have an impact on humanity both mentally and physically. It is usually recognized universally that, religion and spirituality are among the greatest significant cultural factorsgiving structure and sense to conduct, values system, and experiences. Faith is a sophisticated power connected with well-being, and are in an optimistic way. For example, investigators at the Mayo Clinic resolved that most research has revealed that pious involvement and devoutness are 
linked with better healthy life results with greater long life, managing skills, and well-being-related quality of life (even during incurable infection) (Lichter, 2013). The above statement means that researchers have shown that having a concern with the mystical requirements of the patient may improve regaining from sickness. Spirituality and medicine have to interject each other since many seriously ill patients use religious beliefs to cope with their illness... religious involvement is a widespread practice that predicts successful coping with physical illness (Koenig, 1998). In fact, Koenig continues to state that, high intrinsic religiousness predicts more rapid remission of depression, an association that is particularly strong in patients whose physical function is not improving.

Tracy, a physician, and Michael, a theologian, corroborates Koenig and others when they explored the ways in which modern medicine neglects and is potentially hostile towards spirituality, the humanistic concern of paramount value in spirituality and religion. In their book, they recommend among other things, that "both spheres (medicine and theology) become more whole through the light shed from each other." They continue to state that; since the sickness context is an amalgam of nonspiritual, sacred and humanistic fundamentals, it will be most successfully engaged when medical professionals and medical institutions partner with local religious groups and religious counselors and clergymen (Balboni and Balboni, 2018). They argue in hostility to hospitality that future partnership is critical in caring for patients, body, and soul.

To end the discussion, Christina M. Puchalski (2001), identified that aspects of spirituality are relevant for medical doctors in the three most significant areas, that is; mortality, coping, and recovery. In mortality; some empirical studies propose that persons who involve in consistent spiritual practices tend to have a long lifespan. In coping; Patients who are mystical may exploit their beliefs in managing with ailment, discomfort, and stresses in life. Other researchers, concluded that pious individuals have a tendency to have an extra optimistic viewpoint and an improved value of life. Spiritual principles can help sick people to manage illness and face death. When probed what abetted them handle gynecologic cancer, 93\% of 108 women mentioned mystical beliefs. In addition, $75 \%$ of these patients specified that religion had a substantial place in their lives, and $49 \%$ said they had become more mystical after their diagnosis (McNeil et al., 1998). Lastly, in recovery, the spiritual obligation has a tendency to improve recovery from sickness and surgical procedure, (Pulchalski, 2001). Maybe spiritual contemplations empower individuals to be less anxious having some comfort hence living the current life and not being controlled by the past life.

The above studies have manifested that there is an ardent necessity to assimilate the spiritual and religious extents of the sick into their medical administration. The quarantine and isolation facilities lack this which is essential for a full recovery and management of the COVID-19 patients and their close family members.

In applying 'spiritual or religious needs' in the hospital framework, Koenig and Vaillant (2009) proposes that health professionals should attempt to comprehend two extensive issues, Firstly, the patient's essential beliefs which are connected to their well-being hence have consequent in making decisions, managing, sustenance systems, and obligation. Secondly, patients' requirements about how their beliefs and practices are recognized and reinforced while in hospitals. He adds that, the medic's autopsy about the spiritual beliefs and practices of patients should not affront the people without beliefs which are supernatural hence, the inquiry ought to be done in a subtle and reverential way.

However, besides the various optimistic consequences that religious spirituality may present on well-being, they can also have undesirable consequences. All humanity regardless of their spiritual affiliation may experience delicate psychological, communal, and mystical tensions related to religious beliefs that bring anxiety to the sick and their family members. The anxiety can also influence their sustenance system. The spiritual inclinations can make the sick to refuse medical treatment and human supporting care. Some religious fundamentalists may choose faith instead of medicine. 
Unknown in life is more pleasing than faith- the one prodigious touching force which we can neither weigh in the balance nor test in the container... faith has always been a vital factor in the exercise of medicine. It is not only a psychologist but a regular clinical physician also. This is because faith makes the weak in body and mind to become strong (D'Souza, 2007). The relief passed when a health practitioner cares the essential that gives the sick's lifespan sense and optimism is what the majority of sick people want in any health care facility.

\section{CHALLENGES RELIGION AND CULTURE MAY PRESENT TO THE SPREAD OF COVID-19}

Though, science and religion may mutually benefit from each other, there are some situations in which some religious, cultural rituals and beliefs contradict and hence become a challenge in a case where a blend of the two is required to give a solution, as in the case of Corona-virus pandemic. The following could be a challenge to the mitigating factors against the spread of Coronavirus in Kenya.

Alleged Causality of Ailments and Death: observance to given protective procedures by persons in affected societies is essential to a required result in the fight against COVID-19. An overall deficiency of knowledge about the disease etiology can, however, undesirably affect the degree of loyalty to protective procedures (Sabuni, 2007). In African situations, ailments and death are commonly supposed to originate from the ordinary and hypothetical realm (Mbiti, 1975). Hypothetical roots involve the mystical dominion such as witchery and castigation from God or familial spirits for breaching prohibitions and several procedures of wrongdoings (Sabuni, 2007). Undeniably, this thinking pattern can possibly bring some problems to the common personalities in societies that are affected to completely comprehend the origin of COVID-19-associated mortalities as an epidemiologic contagion. They may look for other possible avenues to seek treatments and answers for the cause of disease, especially in cases of death without any symptom of Corona-virus.
Moreover, Kenya and Africa are a place of most speedily growing world religions like Christianity and Islam. Both their sacred texts contain verses and suras dealing with causes of communicable diseases. For example, frequently quoted verses in the Bible include, Deuteronomy 28:20-22 which states that the Lord attacks people with plaques, curses, confusions, fever and inflammations and 2 Chronicles 7:13,14 where it is stated that, "if I command the locust, or if I send pestilence among my people; if my people who are called by my name, shall humble themselves, and pray... I will forgive their sins, and will heal their land". Some religious preachers falsely quote the incidence of Corona-virus as God-perpetrated penalty for involving in practices like bribery, human killings during the post-election violence in Kenya and evil deals by the religious people. The way people intellectualize the etiology of a given ailment usually commands their response to it. Given that, in Kenya, the $\mathrm{MOH}$ reported that one case of COVID-19 was of an herbalist, it is not surprising that it is possible that some herbalists or diviners are being referred for the handling of the disease. This could be very risky in cases of people who are asymptomatic. In view of the probable impact of etiological theories of people's response to inhibition and handling of the disease, a knowledge of the background of the opinions of the persons in the affected societies on roots of Corona-virus is essential in vindicating the undesirable influence of such opinions on the spread of the virus.

Traditional and Spiritual Curing. Although contemporary disease treatment built on the Western drug is currently well-thought-out as the standard in Africa, some societies in Africa and Kenya for our case, still trust profoundly on traditional therapeutic practices. In Kenya Centre for Traditional Medicine Research (CTMDR) is a center within the Kenya Medical Research Institute (KEMRI). This shows that the use of traditional medicine is legalized in Kenya; hence majority may use it. As reported by Mutahi Kagwe, the Cs for Heath through the media, reported than an herbalist contracted the COVID -19. It can be insinuated that traditional healers are regarded in this era. Although old-style medication may provide a constructive part in contemporary hospital management, some old therapeutic opinions and practices may result in a grave undesirable influence on the medical result 
and spread of the virus. For example, the herbalist who tested positive for COVID-19 in Kenya may be as a result of this. Hewlett and Hewlett (2007) reported similar claims during the Ebola outbreak. He gives a case of traditional doctors in Uganda who were making cuts into people's bodies and rubbing herbal medicine in. This increased the spread of Ebola. This case may be an imminent challenge in the spread of Coronavirus in Kenya, especially in cultures where traditional healers are still of high value. In this case the Ministry of Health should totally barn the use of herbal or traditional healing. Some researchers like Manguwo and Mafuvadze (2015) suggest in their research concerning the spread of Ebola disease that, qualified traditional therapists can be engaged to assist other old-style and religious healers to have knowledge on the origin, transmissions, spread and management of the virus in their society. They continue to suggest the suspension of healing activities until the proponents get adequate knowledge or hold scientific skills.

Rituals and ceremonies related to Committal Practices. several tribes in Kenya believe in life beyond this current life. Subsequently, this belief in life after death affects the funerals and burial rituals in the community. This is because they are considered to escort the deceased from the world of the living to the spiritual world of the spirits and ancestors (Mbiti, 1975). The transition should be organized by the close members of the bereaved through descent burial according to the rank of the departed. If the deceased is not given a worthy burial, then these societies believe that his/her spirits will continue to hover and punish the living. Among the communities with such detailed funeral rituals are Luo and Luhya communities. One such ritual which significantly may pay to the spread of the Corona-virus is the washing and cleaning of the dead body, the removal of the pant of the married woman, and set in the position of the reproductive part of the male in case he has left behind a window. In all these activities, there has to be bodily contact with the deceased notwithstanding the obvious undesirable effect on the transmission of Coronavirus. The majority of African societies, place weighty worth on the rites of funerals and resist the reception of alternate methods lessening the transmission of the virus such as cremation, (Manguwo \& Mafuvadze, 2015) or use of common government graveyard. Against this background, the questions that we should ask during epidemics of an ailment such as Corona-virus are: how do we ensure that we follow the laid procedures certify that we abstain from coming in contact with the corpses ?; who ought to certify that such practices are stopped?; how do we ensure decent interment of the dead in conformity with traditional norms but curtailing the likelihoods of transmitting the ailment?; should we entirely stop traditional committal rituals at the expense of scientifically set procedures that seemingly lessen the transmission of the ailment?. The abandonment of culturally set burial rituals may result in a prolonged psychological problem to the bereaved.

In a determination to lessen the transmission of the Coronavirus, over committal observances, the World Health Organization (WHO), in conjunction with the National Government of Kenya together with the County Governments, set procedures to be followed concerning how remains of COVID-19 fatalities are to be handled and afterward buried (Ogila, 2020). Although the procedures were constituted in conformity with the present logical information of the virus, it is clear that little or no consideration is given to the affected societies in relation to their cultural consequences. Some of the measures, such as speedy disposal of dead bodies usually bring psychological disturbances in some communities. This is due to the belief that, they are in direct conflict with therapeutic burial rituals and widely held views of life after death in the case where the rituals are not adhered to. It may sound as being uncivilized for people outside such culture that some cultures do not comprehend that the extremely communicable feature of the ailment and high mortalities that results from it, necessitate unexpected procedures to hold. Subsequently, it is also vital for people outside such cultures to comprehend that some of these burial practices span across age groups and have been in practice as old as humanity. For example, in an effort to speedily dispose of dead bodies in an effort to lessen the transmission of the Coronavirus disease, "The Siaya COVID-19 County Response Team", already have a case and problem with the bereaved family of the supposed COVID-19 victim. Resultantly, in an effort to avoid cremation of the victims or committal without a family agreement, some of the persons may not report their departed 
kin who may be asymptomatic of the Corona-virus. They may surreptitiously continue with traditional committal rituals hence spread the virus thus frustrating efforts to contest the community transmission of COVID-19. In the process of handling the corpse, they may be infected due to the contact if the victim was COVID-19 positive. This is because, fluids from corpses can put the lives of those examining or handling the bodies at risk. Prof. Emilly Rogena, a pathologist in human pathology quotes a report in the journal of forensic and legal medicine "the pathologist who died in Bangkok came in contact with a COVID-19 corpse" (Ogila, 2020).

In recognition of the uniqueness of each tribal funeral ritual in Kenya, with none, accepting cremation, we propose that the government calls off the cultural burial, in community graves and establish special burial graveyard for deceased victims of COVID-19. It is, thus, our proposal that the community leaders ought to be engaged in finetuning traditional societal rites to degree that are operative in the deterrence of ailment but still communally accepted by the members of the tribe. Consciousness civic education aiming the community leadership e.g. councils of elders, priests, and imams should be launched in zones once an eruption has been inveterate. As supervisors and traditional customs enforcers in the community, community members will easily adhere to their commands that challenge their societal values when directives are given by their own people as compared to people considered to be foreigners.

In a similar manner, religious leaders can refer to their religious texts for some guidelines to hearten their congregants to observe to scriptural commendations on how to deal with the corpse to lessen the spread of communicable diseases. For example, Numbers 19: 11-12, defines how individuals were to ensure body purity with water after coming into contact with a corpse. Equally, in Leviticus 21:10-12, Levites were cautioned never to come to a corpse probably as a way of averting them from transmitting contagions to people within the public where he interacts with the members. Lastly, in the New Testament, acts 5:1-16) Ananias was buried by young men immediately after his death without the knowledge of his wife. Through the pronunciation of such and similar sections from the Quran and Hadith, the imams, priests, and pastors can instill in the mind of their congregants on the importance of lessening the spread of infectious disease by use of extraordinary ways.

\section{RECOMMENDATIONS AND CONCLUSIONS}

The existing COVID-19 pandemic in the world requires the whole societies' involvement and not only the government. This demonstrates that scientifically proven management skills should be a unified program of religion and science. This is because, science has more in common with religion than their differences. Similarly, procedures of fighting the spread of infectious ailments, if not ethnically and conscientiously tolerable towards a society, are probable to be counterattacked. Thus, there is, a necessity to explore and bring into line preventative procedures that are culturally accepted by the affected societies. Where there is irreconcilability between religious and cultural practices and set scientifically protective procedures, the forefront leadership ought to extensively engage and team up with the community leadership. In other words, for societalcreated plans to be effective, the locals through their leaders should be engaged and allotted key roles in the 24-hour care and operation of curbing procedures against the transmissions of the Coronavirus disease.

Another key challenge in the management of the Coronavirus pandemic in Kenya is the issue of who and how management should be done. Is it a spiritual disease as a result of punishment from God as claimed by the majority of religious leaders? Or it is a pathogenic disease that should be left for only science and medics to manage. Here we propose that all the stakeholders should be involved, religion and science should come together for a holistic approach. The medics need knowledge from the Supreme being. In most cases, science does not contradict religion and religion needs science to understand some of its concepts. Religion is also needed for the management of the confirmed cases, this is to provide spiritual services hence providing holistic care of the mind, body, and soul. 
One of the key contests already confronted in the current Coronaviruss pandemic is the lack of a joint trust agreement between 'The COVID-19 Response Team' and the affected members. The distrust was mainly worsened when a burial of COVID-19 victim was done without the family consent and participation. The quick burial of the victim without the consent of family members resulted in a clash between families and The Response team and health officials in court. This may lead to exhumation and result in other health risks and the psychological disturbance of family members as with the case in Siaya County, in Kenya. The consultations of community leadership forum and qualified individuals from societies with the epidemic and plays key roles in the given society is probable to advance consideration and observation of the precautionary procedures. As Alexander et. al. (2014), argue, the majority of Africans often listen and follow ardently their traditional leaders for guidance in times of disastrous strikes hence they are key in the implementation of such procedures.

There is a possibility that the Corona-virus immunization operations will be launched to manage the virus. Previously, polio and tetanus vaccinations for young girls and western medicines were resisted by some groups amid rumors concerning the negative effects of the vaccines and varied religious fundamentalism reasons, that it is against some church doctrines. It is, thus, probable that the achievement of COVID-19 vaccination operations in Kenya, resolve to a huge degree, hinge on the participation of the community leadership (both civil and religious). The campaigns should also precisely target old-style therapists. Considering the religious and cultural principles of the Kenyan people, it is challenging to competently stop the transmission of Coronavirus disease without the support of the community leadership.

\section{REFERENCES}

Alexander, K. A., Sanderson, C. E., Marathe, M., Lewis, B. L., Rivers, C. M., Shaman, J., ... \& Eubank, S. (2015). What factors might have led to the emergence of Ebola in West Africa?. PLoS neglected tropical diseases, 9(6).
Balboni, M. J., \& Balboni, T. A. (2018). Hostility to hospitality: spirituality and professional socialization within medicine. Oxford University Press.

Barbour, Ian. (2000). When Science Meets Religion: Enemies, Strangers, or Partners? New York: HarperCollins.

D'Souza, R. (2007). The importance of spirituality in medicine and its application to clinical practice. Medical Journal of Australia, 186(10), S57.

Ellison, C. G., \& Levin, J. S. (1998). The religionhealth connection: Evidence, theory, and future directions. Health Education \& Behavior, 25(6), 700-720.

Haught, J. F. (1995). Science and Religion; Is Life Reducible to Chemistry? New York: Paulist Press.

Hempel, C. G. (1966). Philosophy of Natural Science. New York: Prentice-Hall.

Hewlett, B. S., \& Hewlett, B. L. (2007). Ebola, culture and politics: the anthropology of an emerging disease. Cengage Learning.

Hummer, R. A., Rogers, R. G., Nam, C. B., \& Ellison, C. G. (1999). Religious involvement and US adult mortality. Demography, 36(2), 273-285.

Kleipe, R. (2011, May 18). Comparing Similarities Between Science and Religion. Retrieved from http://acidrayn.com/2011/05/18/comparingsimilarities-between-science-and-religion/.

Koenig HG, McCullough M, Larson D. (2000). Handbook of religion and health. New York: Oxford University Press,

Koenig, H. G. (1998). Religious attitudes and practices of hospitalized medically ill older adults. International journal of geriatric psychiatry, 13(4), 213-224.

Koenig, H. G., George, L. K., \& Peterson, B. L. (1998). Religiosity and remission of depression in medically ill older patients. American Journal of Psychiatry, 155(4), 536-542. 
Koenig, H. G., McCullough, M., \& Larson, D. B. (2001). Handbook of Religion and Health. New York: Oxford Univ.

Koenig, L. B., \& Vaillant, G. E. (2009). A prospective study of church attendance and health over the lifespan. Health Psychology, 28(1), 117.

Manguvo, A., \& Mafuvadze, B. (2015). The impact of traditional and religious practices on the spread of Ebola in West Africa: time for a strategic shift. The Pan African Medical Journal, 22(Suppl 1).

Mbiti, John S. (1975). Introduction to African Religion. London: Heinemann.

Ogila, J. (2020, April 13). What WHO Says of Handling and Burying COVID-19 Victims. Standard Online. Retrieved from the Standard Digital at standardmedia.co.ke/health/article/2001367887 /what-who-says-of-handling-and-burryingcovid-19-victims.

Puchalski, C. M. (2001, October). The role of spirituality in health care. In Baylor University Medical Center Proceedings (Vol. 14, No. 4, pp. 352-357). Taylor \& Francis.

Sabuni, L. P. (2007). Dilemma with the local perception of causes of illnesses in central Africa: muted concept but prevalent in everyday life. Qualitative Health Research, 17(9), 12801291.

Shahabi, L., Powell, L. H., Musick, M. A., Pargament, K. I., Thoresen, C. E., Williams, D., ... \& Ory, M. A. (2002). Correlates of selfperceptions of spirituality in American adults. Annals of Behavioral Medicine, 24(1), 59-68. 